\title{
Continent Idiopathic Vesicovaginal Fistula Coexisting with Moyamoya Disease
}

\author{
Moyamoya Hastalığıyla Birlikte Kontinan İdiyopatik Vezikovajinal Fistül
}

\author{
İbrahim Güven Kartal, Mehmet Ezer, Tahsin Batuhan Aydoğan, Ali Ergen \\ Hacettepe University Faculty of Medicine, Department of Urology, Ankara, Turkiye
}

\begin{abstract}
The most common cause of vesicovaginal fistula in developed countries is iatrogenic injury whereas in developing countries the leading cause is obstetric complications. Spontaneous vesicovaginal fistula is extremely rare. In this case report, a 23-year-old female patient with moyamoya disease and a stable right ovarian cyst and a vesicovaginal fistula without any underlying factor is discussed. She was fully continent. If there is any possible relationship between vesicovaginal fistula and moyamoya disease, it needs further investigations.
\end{abstract}

Keywords: Continent, idiopathic, incidental, moyamoya disease, vesicovaginal fistula

Öz

Vezikovajinal fistül; gelişmiş ülkelerde en sık iatrojenik nedenlere bağlıyken, gelişmekte olan ülkelerde en sık obstetrik nedenlere bağlıdır. Spontan vezikovajinal fistül çok nadirdir. Yirmi üç yaşında stabil ovaryan kist nedeniyle takipli hastada insidental saptanan nedeni belli olmayan, tamamen kontinan olan olgu sunulmuştur. Moyamoya hastalığı ve vezikovajinal fistül arasında ilişki olduğunu belirlemek için ek çalışmalara ihtiyaç vardır. Anahtar Kelimeler: Kontinan, idiyopatik, insidental, moyamoya hastalığı, vezikovajinal fistül

\section{Introduction}

Vesicovaginal fistula (NF) is the abnormal anatomic communication between the female bladder and vagina. Usually presents itself as continuous urinary incontinence. There are many etiologic risk factors such as obstetric trauma, pelvic surgery, infections, congenital abnormalities, foreign materials, malignancy and pelvic radiation (1). Due to high education and sociocultural levels, the incidence seems to be low in the developed countries. On the other hand, in the developing countries, there is an obviously high incidence and prevalence. Considering the low level of medical informative feed-back mechanisms and poor obstetrics health care services, it seems very hard to keep WF patient data that can be used for epidemiological research studies. In those areas, due to high maternal mortality and obstetric complications, the incidence of WF is significantly increased (2). In this paper, we report a female patient with known moyamoya disease and a stable right ovarian cyst who was regularly followed up by the departments of neurology, gynecology and presented with radiological and cystoscopy findings of incidentally diagnosed asymptomatic continent WF.

\section{Case Presentation}

A 23-year-old obese female patient was first seen 5 years ago in the obstetrics and gynecology outpatient clinic with the complaint of irregular periods. She had regular menstrual periods and no gynecological complaint since then. Transvaginal ultrasonography showed a $17 \mathrm{~mm}$ right ovarian cyst and follow up was recommended.

In 2009, she attended the neurology outpatient clinic with the complaint of recurrent headache. Transcranial Doppler

Correspondence: İbrahim Güven Kartal MD, Hacettepe University Faculty of Medicine, Department of Urology, Ankara, Turkiye Phone: +9031230518 85 E-mail: igk84@hotmail.com ORCID-ID: orcid.org/0000-0002-2313-3522

Received: 03.04.2016 Accepted: 19.08.2016

Cite this article as: Kartal IG, Ezer M, Aydoğan TB, Ergen A. Continent Idiopathic Vesicovaginal Fistula Coexisting with Moyamoya Disease. J Urol Surg 2017;4:140-142.

๑Copyright 2017 by the Association of Urological Surgery / Journal of Urological Surgery published by Galenos Publishing House. 
ultrasonography and cranial magnetic resonance imaging (MRI) revealed a stenotic occlusion at the supraclinoid portion of the right internal carotid artery and decreased blood flow on the right middle cerebral artery suggesting moyamoya disease. She has been followed by the neurology department since then.

At her last visit to the gynecology outpatient clinic in November 2014, a pelvic ultrasonography revealed a $63 \times 60 \times 68 \mathrm{~mm}$ cystic appearance presenting with an internal echo pattern in the genital tract. Further radiological investigation done

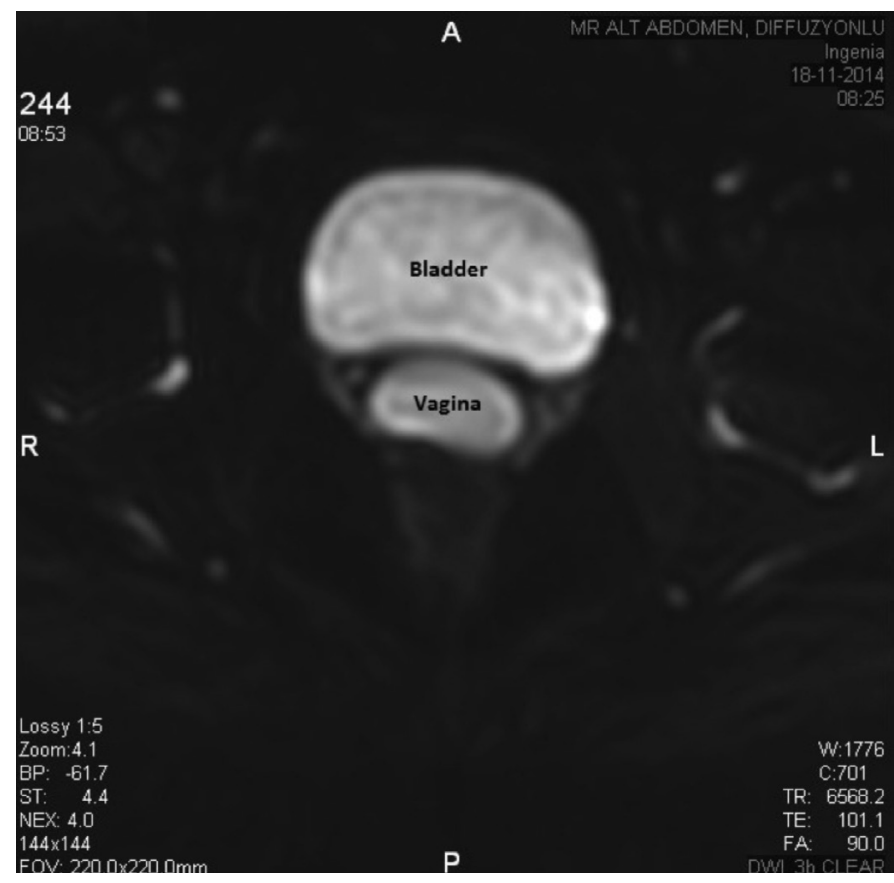

Figure 1. Magnetic resonance imaging scan showing the contrast material filled the vagina

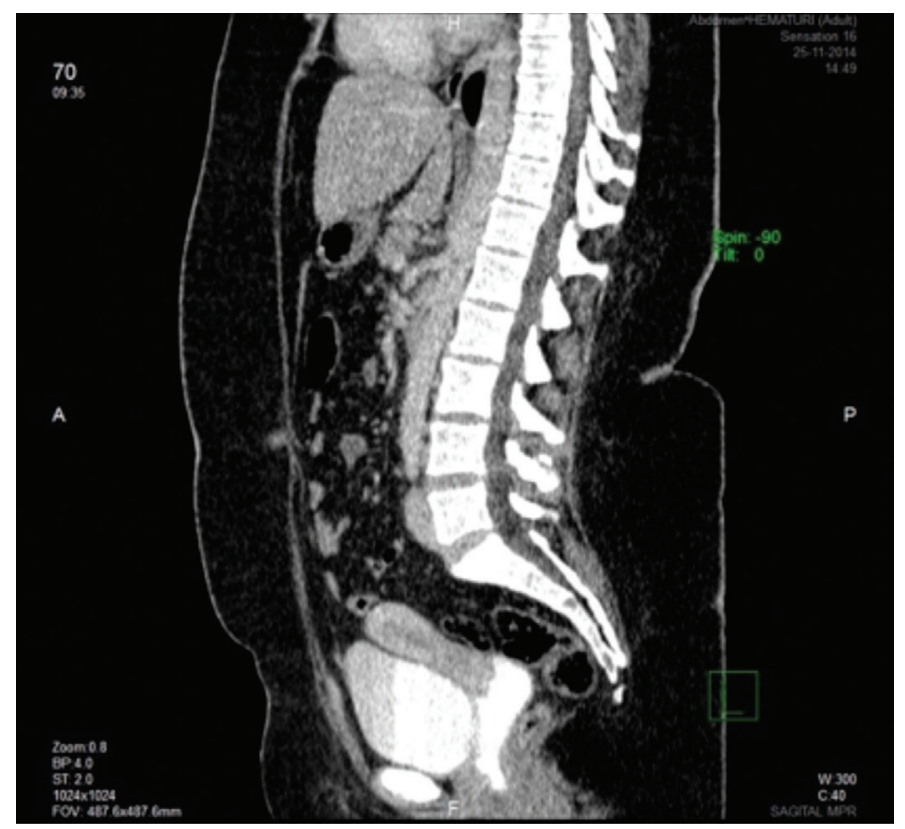

Figure 2. Computed tomography scan showing the mid vaginal fistula tract and the filled vagina with the same intensity of the urine in the bladder by an abdominopelvic MRI showing at the beginning of the screening that the vagina seemed to be normal but on the $30^{\text {th }}$ minutes, radiopaque intensity of the bladder was same with the appearance of the vagina without an obvious WF tract (Figure 1). She was referred to our female urology department. We planned computed tomography (CT) urography for identification of the possible fistula tract. On the CT scan, the urine including contrast material filled the vagina through a WF tract in the mid vagina (Figure 2). After complete micturition, the vagina and the bladder completely emptied.

On her gynecological examination it was observed that she had an intact annular hymen with no history of any sexual intercourse, urogenital trauma, pelvic surgery, labor or pelvic radiotherapy predisposing to the occurrence of WF. Her routine urine analysis and urine culture revealed no pyuria, bacteriuria nor microscopic hematuria.

The fistula tract was identified in the bladder by flexible cystoscopy and verified by administration of methylene blue. Although WF repair was recommended, the neurology department did not clear her for any type of anesthesia. At this point, routine follow-up was recommended.

\section{Discussion}

This case is unique and extraordinary because of complete continence and having none of the underlying etiological factors related to WF as we searched the literature. Normally being an asymptomatic patient relieved the presence of fistula tract under the radiological examination due to over-distended bladder.

WF leads to continuous incontinence and urinary leakage that gradually affects the patient's psychosocial situation and physical health. WF patients have a higher incidence of suffering from depression, anxiety and other psychological disorders (3).

Moyamoya disease is a radiologically diagnosed disease which presents generally intimal thickening of the distal segments of inferior cerebral artery also proximal segments of the anterior and middle cerebral arteries. The underlying mechanism of the disease are not well understood. Due to the stenotic segments, the arterial blood flow decreases and weak collaterals develop in order to ensure the blood supply to these areas. This appearance on the radiological images looks like "puff of smoke" which is called moyamoya in Japanese (4). The typical histological finding of the disease is intimal thickening of the arteries without vasculitis. Moyamoya disease is well described and having a high incidence in the Far East areas especially in the Japanese population, nevertheless, a few studies in the literature showed that the disease could also be seen in the Western populations 
and other ethnic groups (5). Few case reports also described extracranial presentation of moyamoya disease (6). In our case, we could not clearly describe a relationship between the pelvic arterial blood supply alteration due to moyamoya disease and pelvic ischemia leading to formation of WF.

Moyamoya disease has high morbidity and risks of perioperative complications and outcomes related to general anesthesia which restrict the use of anesthetic agents (7). We informed the patient about the untreated WF risks and complications, such as recurrent urinary tract infections and altered kidney functions due to chronic irritation leading to malignant transformation. She did not accept any treatment modality. Follow-up was recommended since there was no residual urine in the bladder and the vagina.

Due to full continence and no underlying etiological factors leading to $\mathrm{WF}$, this is the first and unique case reported in the literature. Although moyamoya disease rarely shows extracranial presentation such as pelvic arterial alteration, WV might be related with it. It could be taken into consideration that small diameter WF and asymptomatic WF with high anesthesia risks could be followed up without any surgical treatment. Although we could not obviously show a relationship between moyamoya disease and WF leading the formation of WF further investigations are warranted.

\section{Ethics}

Informed Consent: Consent form was filled out by the participant.

Peer-review: Externally peer-reviewed.

\section{Authorship Contributions}

Surgical and Medical Practices: I.G.K., A.E., Concept: I.G.K., M.E., Design: I.G.K., T.B.A., Data Collection or Processing: I.G.K., Analysis or Interpretation: I.G.K., T.B.A., Literature Search: I.G.K., M.E., Writing: I.G.K.

Conflict of Interest: No conflict of interest was declared by the authors.

Financial Disclosure: The authors declared that this study received no financial support.

\section{References}

1. Angioli R, Penalver M, Muzii L, Mendez L, Mirhashemi R, Bellati F, Crocè $C$, Panici PB. Guidelines of how to manage vesicovaginal fistula. Crit Rev Oncol Hematol 2003;48:295-304.

2. De Ridder D. Vesicovaginal fistula: a major healthcare problem. Curr Opin Urol 2009;19:358-361.

3. Goh JT, Sloane KM, Krause HG, Browning A, Akhter S. Mental health screening in women with genital tract fistulae. BJOG 2005;112:1328-1330.

4. Fukui M. Guidelines for the diagnosis and treatment of spontaneous occlusion of the circle of Willis ('moyamoya' disease). Research Committee on Spontaneous Occlusion of the Circle of Willis (Moyamoya Disease) of the Ministry of Health and Welfare, Japan. Clin Neurol Neurosurg 1997;99(Suppl 2):238-240.

5. Chiu D, Shedden P, Bratina P, Grotta JC. Clinical features of moyamoya disease in the United States. Stroke 1998;29:1347-1351.

6. Kaczorowska M, Jozwiak S, Litwin M, Kmiec T, Kuczynski D, Jurkiewicz E, Koscierza I. [Moyamoya disease associated with stenosis of extracranial arteries: a case report and review of the literature]. Neurol Neurochir Pol 2005;39:242-246.

7. Brown SC, Lam AM. Moyamoya disease--a review of clinical experience and anaesthetic management. Can J Anaesth 1987;34:71-75. 